\title{
Cardiac Myxoma among Patients Undergoing Cardiac Surgery in a Tertiary Care Center: A Descriptive Cross-sectional Study
}

Prabhat Khakural,' Ravi Baral,' Anil Bhattarai,' Bhagawan Koirala'

'Department of Cardiothoracic and Vascular Surgery, Manmohan Cardiothoracic Vascular and Transplant Center, Maharajgunj Medical Campus, Institute of Medicine, Maharajgunj, Kathmandu, Nepal.

\section{ABSTRACT}

Introduction: Heart neoplasms are rare tumors. Myxoma is the commonest primary benign tumor of the heart presenting with features of obstruction, arrhythmia, and embolism. Surgical excision of the tumor is the gold standard of treatment. The aim of the study is to find out the prevalence of cardiac myxoma among all cardiac surgeries operated during the study period.

Methods: A descriptive cross-sectional study was done among 3800 patients undergoing surgery for cardiac tumors in a tertiary care center after obtaining approval from the Institutional Review Committee (Reference number- 36/(6-11)E2/077/078). The data was collected retrospectively from August 2012 to August 2020 using convenience sampling method. Statistical analysis was performed using Microsoft Excel 2016. Point estimate at 95\% Confidence Interval was calculated along with frequency, percentage, mean and standard deviation.

Results: There were 26 (0.68\%) (0.42-0.94 at 95\% Confidence Interval) myxoma among 3800 cardiac surgeries performed over eight years. The mean age of the patients was $54.76 \pm 14.31$ (range 17-75) years. Twenty $(76.92 \%)$ patients were females. The commonest presenting symptom was shortness of breath in 19 (73.07\%) patients. En masse excision with the closure of the atrial septal defect was the principal surgical technique. The mean Intensive Care Unit stay and hospital stays were $2.92 \pm 1.29$ and 6.26 \pm 2.61 days respectively. There was no perioperative mortality.

Conclusions: Cardiac myxoma was the most common cardiac tumor encountered as in other studies.

Keywords: embolism; heart neoplasms; myxoma.

\section{INTRODUCTION}

Cardiac tumors are rare tumors with a prevalence of 0.0017 to $0.28 \% .^{1}$ Metastatic tumor of the heart is commoner than benign tumors with a prevalence of $1 \%$ and $0.1 \%$, respectively. ${ }^{2}$ The ratio of occurrence of primary benign to malignant cardiac tumors is $2: 1 .^{3}$ Myxoma and sarcoma are the commonest benign and malignant cardiac tumors respectively. ${ }^{4}$

Myxoma affects women in the $3^{\text {rd }}-6^{\text {th }}$ decades of life more frequently. ${ }^{5}$ Such patients present with features of valvular obstruction, heart failure, arrhythmia, embolization, and constitutional symptoms. ${ }^{6}$ Heart neoplasms are diagnosed by echocardiogram, computed tomography, magnetic resonance imaging. ${ }^{7}$ Benign tumors are treated with complete surgical resection whereas malignant tumors need to be completely excised as far as possible and treated with adjuvant chemotherapy and radiotherapy. ${ }^{8}$

Researches on the cardiac tumor from Nepal are scarce. This study is intended to find out the prevalence of cardiac myxoma among all cardiac tumors operated in our center during the study period.

Correspondence: Dr Prabhat Khakural, Department of Cardiothoracic and Vascular Surgery, Manmohan Cardiothoracic Vascular and Transplant Center, Maharajguni Medical Campus, Institute of Medicine, Maharajgunj, Kathmandu, Nepal. Email: pkhakural@gmail.com, Phone: +977-9841293877. 


\section{METHODS}

This was a descriptive cross-sectional study conducted in the Department of Cardiothoracic Vascular Surgery in Manmohan Cardiothoracic Vascular and Transplant Center, Maharajgunj, Kathmandu, Nepal. The data was collected retrospectively from August 2012 to August 2020 through medical records. Ethical approval was obtained from the Institutional Review Committee (IRC) of Institute of Medicine (Reference number: 36/ (6-11) $\left.E^{2} / 077 / 078\right)$. Convenience sampling technique was used and sample size was calculated according to the formula:

$$
\begin{aligned}
\mathrm{n} & =Z^{2} \times \mathrm{p} \times \mathrm{q} / \mathrm{e}^{2} \\
& =(1.96)^{2} \times 0.5 \times(1-0.5) /(0.02)^{2} \\
& =2401
\end{aligned}
$$

Where,

$\mathrm{n}=$ minimum required sample size

$\mathrm{Z}=1.96$ at $95 \%$ of Confidence Interval $(\mathrm{Cl})$

$\mathrm{p}=$ prevalence taken as $50 \%$ for maximum sample size $q=1-p$

$\mathrm{e}=$ margin of error, $2 \%$

Adding a $10 \%$ non-response rate, the calculated sample size was 2641 . However, 3800 cases were taken.

Data collected from patient files included patient characteristics- age, gender, New York Heart Association (NYHA) class, presentation of cardiac tumors, intraoperative tumor size, cardiopulmonary bypass time, aortic cross-clamp time, postoperative hours of ventilation, mediastinal drainage, postoperative complications, duration of hospital and Intensive Care Unit (ICU) stay, histopathology of a tumor, in-hospital and long-term survival. Long-term survival was studied by reviewing the follow-up record and telephonic interview.

Data were recorded and descriptive statistics like frequency, percentage, mean and standard deviaton were calculated using Microsoft Excel 2016. Point estimate at $95 \%$ Confidence Interval was also calculated.

\section{RESULTS}

Among 3800 cardiac surgeries, 26 (0.68\%) (0.42-0.94 at 95\% Confidence Interval) were performed for cardiac myxoma. The mean age of the patients with myxoma was $54.76 \pm 14.31$ years (range 17-75). Eleven (42.30\%) of the patients were in the $50-59$ years group. The majority of the patients were females, with a female to male ratio of 3.3:1. The mean duration of symptoms was $119.84 \pm 134.11$ days. Two cases were diagnosed incidentally while being worked up for hypertension. The presenting symptoms were shortness of breath, palpitation, cough, anorexia with weight loss, and features of embolism (Table 1). Only six (23.07\%) patients with cardiac myxoma had a history of smoking. The most common tumor location was the left atrium followed by the right atrium. Tricuspid regurgitation was the commonest associated valvular dysfunction followed by mitral regurgitation (Table 1). One patient

\begin{tabular}{|c|c|c|}
\hline Variables & & n (\%) \\
\hline \multirow[t]{2}{*}{ Gender } & Male & $6(23.07)$ \\
\hline & Female & $20(76.92)$ \\
\hline \multirow{6}{*}{$\begin{array}{l}\text { Presenting } \\
\text { symptoms }\end{array}$} & Dyspnoea & $19(73.07)$ \\
\hline & Palpitation & $14(53.84)$ \\
\hline & Embolism & $4(15.38)$ \\
\hline & Fever & $1(3.84)$ \\
\hline & $\begin{array}{l}\text { Anorexia and weight } \\
\text { loss }\end{array}$ & $4(15.38)$ \\
\hline & Cough & $4(15.38)$ \\
\hline \multirow[t]{4}{*}{ NYHA class } & I & $1(3.84)$ \\
\hline & II & $16(61.53)$ \\
\hline & III & $9(34.61)$ \\
\hline & IV & - \\
\hline \multirow{9}{*}{$\begin{array}{l}\text { Smokers } \\
\text { Echocardiogram } \\
\text { findings }\end{array}$} & & $6(23.07)$ \\
\hline & Tumor site & \\
\hline & Left atrium & $23(88.46)$ \\
\hline & Right atrium & $2(7.69)$ \\
\hline & Left ventricle & $1(3.84)$ \\
\hline & $\begin{array}{l}\text { Tumor protrusion } \\
\text { through mitral valve }\end{array}$ & $14(53.84)$ \\
\hline & Mitral regurgitation & $6(23.07)$ \\
\hline & $\begin{array}{l}\text { Tricuspid } \\
\text { regurgitation }\end{array}$ & $8(30.76)$ \\
\hline & $\begin{array}{l}\text { Severe pulmonary } \\
\text { artery hypertension }\end{array}$ & $3(11.53)$ \\
\hline
\end{tabular}
had functional mitral stenosis whereas another one had an organic stenotic lesion.

All the patients with myxoma underwent complete excision of the tumor. A separate right and left atriotomy (Bicameral approach) was the most commonly employed approach (Table 2). A total of 14 (53.84\%) patients had myxoma with a broad base whereas the remaining tumors were pedunculated. Piecemeal excision of the very friable tumors was performed. The majority of the tumors were excised with a wide rim of interatrial septal attachment followed by the repair of the interatrial septum either with a pericardial patch or direct closure (Table 2). Aortic cross clamp time was $30.46 \pm 14.52$ minutes and cardiopulmonary bypass time was $46.19 \pm 18.19$ minutes. Adjunct procedures performed included tricuspid valve repair, mitral valve repair, mitral valve replacement, and coronary artery bypass grafting. 
Khakural et al. Cardiac Myxoma among Patients Undergoing Cardiac Surgery in a Tertiary Center: A Descriptive Cross-sectional...

\begin{tabular}{|c|c|c|}
\hline Variables & & n (\%) \\
\hline \multirow[t]{3}{*}{ Approach } & $\begin{array}{l}\text { Bicameral (left atriotomy } \\
\text { and right atriotomy) }\end{array}$ & $22(84.61)$ \\
\hline & Left ventriculotomy & $1(3.84)$ \\
\hline & Right atriotomy & $3(11.53)$ \\
\hline \multirow{2}{*}{$\begin{array}{l}\text { Tumor } \\
\text { attachment }\end{array}$} & Pedunculated & $12(46.15)$ \\
\hline & Sessile & $14(53.84)$ \\
\hline \multirow{2}{*}{$\begin{array}{l}\text { Tumor } \\
\text { excision }\end{array}$} & En masse & $21(80.79)$ \\
\hline & Piecemeal & $5(19.23)$ \\
\hline \multirow[t]{3}{*}{$\begin{array}{l}\text { Procedure } \\
\text { for tumor }\end{array}$} & $\begin{array}{l}\text { Excision with suturing of } \\
\text { endocardium }\end{array}$ & $7(26.92)$ \\
\hline & $\begin{array}{l}\text { Excision with IAS rim with } \\
\text { direct closure of defect }\end{array}$ & $6(23.07)$ \\
\hline & $\begin{array}{l}\text { Excision with IAS rim with } \\
\text { pericardial patch closure } \\
\text { of defect }\end{array}$ & $13(50.00)$ \\
\hline \multirow{5}{*}{$\begin{array}{l}\text { Adjunct } \\
\text { procedure }\end{array}$} & Kay's annuloplasty of TV & $1(3.84)$ \\
\hline & Ring annuloplasty of TV & $1(3.84)$ \\
\hline & $\begin{array}{l}\text { Commissural } \\
\text { advancement of mitral } \\
\text { valve }\end{array}$ & $2(7.69)$ \\
\hline & Mitral valve replacement & $1(3.84)$ \\
\hline & $\begin{array}{l}\text { Coronary artery bypass } \\
\text { grafting }\end{array}$ & $1(3.84)$ \\
\hline
\end{tabular}

The majority of the patients were extubated the same day, had insignificant mediastinal drainage and stayed in ICU and hospital for an average period of $2.92 \pm 1.29$ and $6.26 \pm 2.61$ days respectively (Table 3 ). Seven $(26.92 \%)$ of the patients had arrhythmias requiring intervention (Table 4). One patient developed hemiparesis in the postoperative period which got improved by the time of discharge. The CT head of the patient did not reveal ischemia or hemorrhage. There was no perioperative mortality.

\begin{tabular}{|ll|}
\hline \multicolumn{2}{|l|}{ Table 3. Post-operative variable. } \\
\hline Variables & Value (Mean \pm SD) \\
Ventilation support (hours) & $7.91 \pm 6.27$ \\
Mediastinal bleeding (ml) & $272.50 \pm 192.66$ \\
ICU stay (days) & $2.92 \pm 1.29$ \\
Hospital stay (days) & $6.26 \pm 2.61$ \\
Drain placement (days) & $1.57 \pm 0.64$ \\
\hline
\end{tabular}

\begin{tabular}{|ll|}
\hline Table 4. Post-operative complications. \\
\hline Variables & $\mathbf{n}(\%)$ \\
Arrhythmia & $7(26.92)$ \\
Cerebrovascular accident & $1(3.84)$ \\
Heart failure & $1(3.84)$ \\
Renal impairment requiring dialysis & $1(3.84)$ \\
Perioperative mortality & - \\
\hline
\end{tabular}

The patients followed up for a mean period of 1.49 years (range 7 days to 6.5 years). A review of medical records and telephonic interviews identified five late deaths.

\section{DISCUSSION}

In our study $89 \%$ of surgically treated cardiac tumors was myxoma similar to Keeling IM, et al. who found that $86 \%$ of surgically treated cardiac tumors were cardiac myxomas. ${ }^{9}$ The incidence of cardiac myxoma is $0.3 \%$ in patients undergoing on-pump cardiac surgeries. ${ }^{10}$ Cardiac myxoma excision contributed to $0.68 \%$ of cardiac surgeries in our centre. Of the primary cardiac tumors, cardiac myxoma were $92.85 \%$ and $7.14 \%$ were malignant tumors. The majority of the patients, 20 (76.92\%) with myxoma were females and the mean age was found to be $54.76 \pm 14.31$ years. In a study by Mandal sc, et al. the female to male ratio of myxoma occurrence ratio was $1.9: 1$ and $(43 \%)$ of patients were in the $4^{\text {th }}$ to $5^{\text {th }}$ decade of life..$^{11}$ The mean age of the patients was 55 years (range 22-79 years) in a study by Keeling IM, et al. ${ }^{9}$ The mean duration of onset of symptoms to diagnosis was $119.84 \pm 134.11$ in our population.

The most common presenting complaint of the patients included shortness of breath followed by palpitation and $16(61.52 \%)$ patients were in NYHA class II, in our study which is similar to that reported in other studies. Fifty-one percent $51.0 \%$ presented with dyspnea and $65.78 \%$ were in NYHA Class II. ${ }^{10,12}$ Two (7.69\%) patients had a preoperative stroke and two (7.69\%) had femoral artery embolism in our center. In another study from Pakistan, $50 \%$ of patients had neurological symptoms at presentation including stroke and transient ischemic attack, and $14 \%$ had limb ischemia secondary to embolism. ${ }^{13}$ Similarly preoperative atrial fibrillation was seen in $3.84 \%$ in our study. Cianciulli TF, et al. found $9.3 \%$ patients had atrial fibrillation. ${ }^{5}$ Similar to our findings, $82.4 \%-86.6 \%$ of the myxoma was located in the left atrium attached to the interatrial septum. ${ }^{11,14}$ Protrusion of the tumor through the mitral/ tricuspid valve can give rise to symptoms of valvular obstruction, increased pulmonary artery pressure, and tricuspid regurgitation. Fourteen (53.84\%) of our patients had myxoma protrusion through the mitral valve whereas eight $(30.76 \%)$ patients had varying grades of tricuspid insufficiency.

Various operative approaches to myxoma excision have been described in literature like minimally invasive, endoscopic, and robotically-assisted techniques, however, median sternotomy remains the most commonly performed one. ${ }^{2}$ All our patients underwent median sternotomy. The tumor size ranged from $2 \mathrm{~cm}$ to $8 \mathrm{~cm}$, with a mean size of $4.13 \pm 1.39 \mathrm{~cm}$. The majority of the tumors $53.84 \%$ were broad-based. Tumor size ranged from $1 \mathrm{~cm}$ to $12 \mathrm{~cm}$ and $67.6 \%$ to $85.48 \%$ of the tumors were pedunculated in other studies. ${ }^{14,15}$ Complete excision of the tumor is of utmost importance in managing cardiac tumors. Hence the 
Khakural et al. Cardiac Myxoma among Patients Undergoing Cardiac Surgery in a Tertiary Center: A Descriptive Cross-sectional...

commonest approach for left atrial myxoma excision was the bicameral approach in $22(84.61 \%)$ patients. $21(80.79 \%)$ of our patients underwent en masse excision of the tumor and $13(50 \%)$ underwent excision of the tumor along with a portion of the interatrial septum and the defect closure with an autologous pericardial patch. Similar approaches and techniques were followed by other surgeons. ${ }^{16}$ Various studies have shown patients with myxoma excision may need concomitant procedures like mitral valve and tricuspid valve repair or replacements, coronary artery bypass grafting. ${ }^{16}$ Tricuspid repair was done by Kay's annuloplasty in one patient and ring annuloplasty in another patient. One patient underwent mitral valve replacement with excision of the tumor and another patient underwent coronary artery bypass grafting to a distal right coronary artery. The mean cardiopulmonary bypass time and aortic cross-clamp time were found to be $46.19 \pm 18.19$ minutes and $30.46 \pm 14.52$ minutes in our study. However longer mean cardiopulmonary bypass time $(80.7 \pm 39.0$ minutes) and mean aortic cross-clamping time $(51.3 \pm 27.5$ minutes $)$ have also been reported. ${ }^{17}$

The postoperative duration of ventilation was $7.91 \pm 6.27$ hours in our patients. The mean mediastinal drainage was $272.50 \pm 192.66 \mathrm{ml}$ and the drains were placed for a mean duration of $1.57 \pm 0.64$ days. However, packed cells transfusion was required in two patients only. One patient had hemiparesis; seven patients had arrhythmia in the post-operative period. Two patients had supraventricular tachycardia, two had atrial fibrillation with fast ventricular rate, managed by chemical cardioversion and two patients had ventricular fibrillation requiring electrical cardioversion. One patient had a run of ventricular tachycardia abolished by Lidocaine. One patient with postoperative cardiac failure with renal impairment responded well to medical management and three sessions of dialysis. None of the patients had re-exploration for bleeding or tamponade, sepsis, and surgical site infection.

The mean postoperative intensive care unit stay and hospital stays were $2.92 \pm 1.29$ days and $6.26 \pm 2.61$ days respectively. In the hospital, perioperative mortality was not seen. Most of our patients were from remote areas and hence most of them did not follow up for a long period. The mean follow-up period was 1.49 years. Long-term survival was seen in 21 (80.76\%) patients. There were two late in-hospital mortalities. One patient presented to the Emergency room with acute right lower limb ischemia of 24 hours duration and cardiac failure, one year after myxoma excision. The echocardiographic evaluation revealed recurrence of left atrial myxomatous tumor approximately $2 \mathrm{~cm}$ in size. However, the patient crashed in an emergency and succumbed to the disease before she could be shifted to the operating theatre. Another patient had expired following tricuspid valve replacement for severe tricuspid regurgitation, three years after right atrial myxoma excision. In a telephonic interview, it was found that three patients (above 72 years of age) died at home.

In a study from India, $7.89 \%$ of patients had supraventricular arrhythmias, $5.26 \%$ of patients had an atrioventricular block requiring temporary pacing and the early death rate was $5.88 \%$. $15.78 \%$ of patients were lost to follow-up. There were no late deaths and recurrence. $^{12}$ In a Greek study of 153 patients, the mean ICU stay and hospital stay were 2.0 0.9 days and $8.02 \pm 2.8$ days respectively. Postoperatively, atrial fibrillation was seen in $5.9 \%$, permanent pacemaker insertion was required in $5.2 \%$ and in-hospital mortality due to sepsis was $0.7 \%$. Recurrence was found in $3.3 \%$ of patients in a mean follow-up of $3.7 \pm 4.3$ years. ${ }^{14}$

The limitations of the study were that the small sample size and it was a single-center study.

\section{CONCLUSIONS}

Cardiac myxoma was the most common cardiac tumor in our study as in other published studies performed. Proper diagnosis and management of cardiac myxoma could result in complete and safe excision with low perioperative morbidity and mortality.

\section{ACKNOWLEDGEMENTS}

We would like to acknowledge the Department of CTVS and Medical Records Unit of Manmohan Cardiothoracic Vascular and Transplant Center, Maharajgunj, Kathmandu.

Conflict of Interest: None.

REFERENCES
1. Manduz S, Katrancioglu N, Karahan O, Yucel O, Yilmaz MB. Diagnosis and follow up of patients with primary cardiac tumours: a single-centre experience of myxomas. Cardiovasc J Afr. 2011 Nov-Dec;22(6):310-2. [라bMed | Full Text | DOI]

2. Islam KS. A Snapshot on Myxoma Operation of 62 Patients at National Institute of Cardiovascular Diseases(NICVD), Dhaka, Bangladesh. Bangladesh heart Journal. 2018 Dec

\section{8;33(2):85-9. [Full Text | DOI]}

3. Bossert T, Gummert JF, Battellini R, Richter M, Barten $\mathrm{M}$, Walther $\mathrm{T}$, et al. Surgical experience with 77 primary cardiac tumors. Interact Cardiovasc Thorac Surg. 2005 Aug;4(4):311-5. [PubMed | Full Text | DOI] 
Khakural et al. Cardiac Myxoma among Patients Undergoing Cardiac Surgery in a Tertiary Center: A Descriptive Cross-sectional...

4. Glancy DL, Morales JB Jr, Roberts WC. Angiosarcoma of the heart. Am J Cardiol. 1968 Mar;21(3):413-9. [PubMed | Full $\underline{\text { Text }} \mid \underline{\mathrm{DOI}}]$

5. Cianciulli TF, Cozzarin A, Soumoulou JB, Saccheri MC, Mendez RJ, Beck MA, et al. Twenty Years of Clinical Experience with Cardiac Myxomas: Diagnosis, Treatment, and Follow Up. J Cardiovasc Imaging. 2019 Jan;27(1):37-47. [PubMed $|\underline{\text { Full Text }}| \underline{\text { DOI] }}$

6. Lukacs L, Lengyel M, Szedo F, Haan A, Nagy L, Thomka I, et al. Surgical treatment of cardiac myxomas: a 20-year follow-up. Cardiovasc Surg. 1997 Apr;5(2):225-8. [PubMed | Full Text | DOI]

7. Butany J, Nair V, Naseemuddin A, Nair GM, Catton C, Yau T. Cardiac tumours: diagnosis and management. Lancet Oncol. 2005 Apr;6(4):219-28. [ubMed | Full Text | DOI]

8. Sharma J, Sherchan S, Pradhan S, Rajbanshi B, Koirala R, Tamala R, et al. Primary Cardiac Tumours: Our Experience. Nepalese Heart Journal. 2013 Jul 21;8(1):8-11. [․ㅏll Text | DOI]

9. Keeling IM, Oberwalder P, Anelli-Monti M, Schuchlenz H, Demel U, Tilz GP, et al. Cardiac myxomas: 24 years of experience in 49 patients. Eur J Cardiothorac Surg. 2002 Dec;22(6):971-7. [PubMed | Full Text | DOI]

10. Castells E, Ferran V, Octavio de Toledo MC, Calbet JM, Benito M, Fontanillas C, et al. Cardiac myxomas: surgical treatment, long-term results and recurrence. J Cardiovasc Surg (Torino). 1993 Feb;34(1):49-53. [uㅣㄹed]

11. Mandal SC, Islam MS, Rushel K, Talukder MSH, Uddin MM, Hossain MM, et al. Cardiac Myxoma- 17 Years Experience in a Tertiary Care Centre of Bangladesh. Bangladesh Heart Journal. 2018 Apr 10;32(2):85-8. [Full Text | DOI]

12. Khan MS, Sanki PK, Hossain MZ, Charles A, Bhattacharya S, Sarkar UN. Cardiac myxoma: A surgical experience of 38 patients over 9 years, at SSKM hospital Kolkata, India. South Asian J Cancer. 2013 Apr;2(2):83-6. [라Med | Full Text | DOI]

13. Sultan FA, Syed A, Kazmi K, Dhakam S. Cardiac myxomas--clinical spectrum and outcome. J Coll Physicians Surg Pak. 2006 Aug;16(8):501-3. [PubMed]

14. Karabinis A, Samanidis G, Khoury M, Stavridis G, Perreas $\mathrm{K}$. Clinical presentation and treatment of cardiac myxoma in 153 patients. Medicine (Baltimore). 2018 Sep;97(37):e12397. [PubMed | Full Text | DOI]

15. Bjessmo S, Ivert T. Cardiac myxoma: 40 years' experience in 63 patients. Ann Thorac Surg. 1997 Mar;63(3):697-700. [PubMed | Full Text | DOI]

16. Yuksel A, Saba D, Velioglu Y, Ener S, Ozkan H. Biatrial Approach Provides Better Outcomes in the Surgical Treatment of Cardiac Myxomas. Braz J Cardiovasc Surg. 2016 Jul-Sep;31(4):309-17. [PubMed | Full Text | DOI]

17. Lee KS, Kim GS, Jung Y, Jeong IS, Na KJ, Oh BS, et al. Surgical resection of cardiac myxoma-a 30-year single institutional experience. J Cardiothorac Surg. 2017 Mar 27;12(1):18. [ $\underline{\text { PubMed }}|\underline{\text { Full Text }}| \underline{\text { DOI] }}$

\section{The Author(s) 2022}

This work is licensed under a Creative Commons Attribution 4.0 International License. The images or other third party material in this article are included in the article's Creative Commons license, unless indicated otherwise in the credit line; if the material is not included under the Creative Commons license, users will need to obtain permission from the license holder to reproduce the material. To view a copy of this license, visit http://creativecommons.org/licenses/by/4.0/ 